\title{
Thymol Chemotype Origanum vulgare L. Essential Oil as a Potential Selective Bio-Based Herbicide on Monocot Plant Species
}

\author{
Daniela Grul'ová $^{1, *}$, Lucia Caputo ${ }^{2}{ }^{\circledR}$, Hazem S. Elshafie ${ }^{3}{ }^{\circledR}$, Beáta Baranová ${ }^{1}$, \\ Laura De Martino ${ }^{2} \mathbb{D}$, Vincent Sedlák ${ }^{4}$, Zuzana Gogal'ová ${ }^{4}$, Janka Poráčová ${ }^{4}$, \\ Ippolito Camele $^{3,+}(\mathbb{D})$ and Vincenzo De Feo ${ }^{2,+(\mathbb{D})}$ \\ 1 Department of Ecology, Faculty of Humanities and Natural Sciences, University of Prešov, 17. Novembra 1, \\ 08001 Prešov, Slovakia; beata.baranova@unipo.sk \\ 2 Department of Pharmacy, University of Salerno, I-84084 Fisciano, Italy; lcaputo@unisa.it (L.C.); \\ ldemartino@unisa.it (L.D.M.); defeo@unisa.it (V.D.F.) \\ 3 School of Agricultural, Forestry, Food and Environmental Sciences, University of Basilicata, Viale dell'Ateneo \\ Lucano 10, 85100 Potenza, Italy; hazem.elshafie@unibas.it (H.S.E.); ippolito.camele@unibas.it (I.C.) \\ 4 Department of Biology, Faculty of Humanities and Natural Sciences, University of Prešov, 17. Novembra 1, \\ 08001 Prešov, Slovakia; vincent.sedlak@unipo.sk (V.S.); zuzkagogalova@gmail.com (Z.G.); \\ janka.poracova@unipo.sk (J.P.) \\ * Correspondence: daniela.grulova@unipo.sk; Tel.: +421-948-030-412 \\ + Contribute equally to the work and should be considered as co-last authors.
}

Received: 30 December 2019; Accepted: 27 January 2020; Published: 29 January 2020

check for updates

\begin{abstract}
Searching for new bio-based herbicides is crucial for decreasing chemical pollution, protecting the environment, and sustaining biodiversity. Origanum vulgare is considered a promising source of essential oil with herbicidal effect. The mode of action is not known. The present study focused on (1) comparison of phytotoxic activity of Origanum vulgare EO on monocot (Triticum aestivum and Hordeum vulgare) and dicot species (Lepidium sativum and Sinapis alba); (2) and evaluating other antimicrobial biological activities against phytopatogen bacteria (Clavibacter michiganensis, Pseudomonas syringae pv. phaseolicola, Pseudomonas savastanoi, and Xanthomonas campestris); antifungal activity against Monilinia fructicola, Aspergillus niger, Penicillium expansum, and Botrytis cinerea; cytotoxic activity and antioxidant activity. According to the GC/MS analyses, the EO belongs to the thymol chemotype $O$. vulgare with its high content of thymol $(76 \%)$. Germination of all four species was not influenced by EO. The phytotoxic effect was statistically significant in the monocot species, while in the dicot species the opposite was observed-a stimulation effect, which was also statistically significant. Strong biological activity of $O$. vulgare EO was noted on all phytopatogen bacteria and fungi in the highest dose. Cytotoxic activity showed an $\mathrm{IC}_{50}=50.5 \mu \mathrm{g} / \mathrm{mL}$. Antioxidant activity showed an $\mathrm{IC}_{50}=106.6 \mu \mathrm{g} / \mathrm{mL}$ after $45 \mathrm{~min}$ experimental time. Based on the presented results, it is possible to conclude that thymol chemotype O. vulgare essential oil could be potentially used as a herbicide with selective effects on monocot plant species.
\end{abstract}

Keywords: monocots; dicots; thymol chemotype; phytotoxicity; antimicrobial activity; antifungal activity

\section{Introduction}

Herbicides are still dominant tools used in weed management. A herbicide with a new mode of action (MOA) has not been introduced as a commercial product for more than 25 years [1]. Thus, the discovery of new herbicides with new MOAs is particularly urgent [2]. Based on the ecological and political press on environmental protection, there is new attention on the search for natural 
compounds with herbicidal and/or pesticidal effect [3-5]. Plants and some animals have developed specific mechanisms to protect themselves against enemies by production of secondary metabolites, which could be the source of new herbicides and/or pesticides. Moreover, it is important to evaluate the safety of new herbicides and pesticides because many of them produce adverse neurological effects [6].

Essential oils (EOs) are complex mixtures of mostly terpenoids as plant secondary metabolites. It has been recognized that various EO components act as multi-target molecules exerting several MOAs in the recipient-organism $[7,8]$, that can be beneficial compared to conventional herbicides which induce resistance [9]. Single EO molecules are able to cross the cell wall and directly interact with the plant plasma membrane, which is one of the potential cellular targets of EOs. It is known that while monoterpenes disturb the lipid organization and/or domain formation, phenylpropanoid could interact with membrane receptors [9].

The use of plant EOs as possible synthetic substitutes has attracted a high interest from many scientists all over the world [5,10-12]. Volatile terpenes and EOs have been reported as regulators of germination and growth of other species in several ecosystems [13].

Origanum vulgare L. (Lamiaceae) is an aromatic plant, commonly known as oregano, widespread in Mediterranean region as well as other European countries [14-16]. It is a rich source of EO which has proven to possess a wide variety of biological activities. Variable effects of oregano species, not only $O$. vulgare but also O. heracleoticum L., O. majorana L., O. acutidens (Hand.-Mazz.) Ietsw, and O. onites L. have been considered to be due to their bioactive ingredients such as thymol and carvacrol, which act in a synergistic manner, as well as others such as linalool, $\gamma$-terpinene, or cis- and trans-sabinene hydrate [17-21]. The composition of EOs from the same plant species can vary considerably, depending on the several factors such as growth conditions of the plant and the genetics of the variety of the plant species [2]. O. vulgare EO showed promising antibacterial, antifungal, and antiviral activities against several phytopathogens [11,22-25]. Oregano EO was able to inhibit significantly some phytopathogens such as Botrytis cinerea Pers., Penicillium expansum Link, Phytophthora citrophthora (R.E. Sm. and E.H. Sm.) Leonian, Rhizopus stolonifera Vuillemin, Aspergillus niger van Tieghem, Fusarium oxysporum von Schlechtendal, Sclerotinia sclerotiorum (Lib.) de Bary, Staphylococus aureus Rosenbach, Clavibacter michiganensis corrig. (Smith), and Xanthomonas vesicatoria (Doidge) Dowson [24-26].

O. vulgare as well as relative species as O. heracleoticum L., O. majorana L., and O. acutidens have been tested for its phytotoxic effect on dicotyledonous model plant species (Lepidium sativum L., Raphanus sativus L., Lactuca sativa L., and Solanum lycopersicum (L.) H. Karst.; Amaranthus retroflexus L., Chenopodium album L., and Rumex crispus L.) [5,27]. Scientific studies noted potential phytotoxic effect of $O$. vulgare which were tested on various dicot plant species (Sinapis arvensis L., Phalaris canariensis L., Lepidium sativum and Raphanus sativus.; Abutilon theophrasti Medik., Agrostemma githago L., and Medicago sativa L.) $[13,25,28,29]$.

However, monocot plant species, for example cereal grains, present a staple food that provides more food energy worldwide than any other type of crop. Corn (maize), wheat, and rice-in all of their varieties-account for $87 \%$ of all grain production worldwide [30]. Crop protection of such important food sources then depends on selective modes of action in the use of used herbicides. On the other hand, there are a lot of weed plant species, which are monocot (Poa annua L., Hordeum jubatum L., Eleusine indica L., Bromus tectorum L. etc.) and have negative impact on dicot crops. Producing herbicidal EOs with optimal constituents and MOA would be attractive, but little is known of the contributions and interactions of the different components of the EOs that are sold as herbicides [2]. The regulation of both existing and new herbicides has required more extensive toxicology and environmental testing [31].

The EO of one species can vary, depending on chemotype. A chemotype is a "chemical race", meaning that plants sharing the same botanical name (same genus and species) can exhibit a completely different chemical composition [32].

Based on our knowledge, there is no evidence in the scientific literature that $O$. vulgare-thymol chemotype EO was tested for potential phytotoxic effects with a selective effect on monocot and dicot model plant species. All previous studies focused on dicot species. 
The main aim of the current study was to focus on the comparison of potential selective herbicidal activity of oregano EO. Additional bio-chemical and biological assay as GC/MS analysis of EO, antimicrobial and antifungal activity against some phytopathogens, as well as cytotoxic and free radical-scavenging capacity of oregano $\mathrm{EO}$ have been provided, to study the complexity of its biological activity. If there is an assumption that the EO of oregano could be used in agrosystems as a bio-based herbicide, it is very important to mention that agrosystems present a complex ecological system, where all living beings are in interaction. It was very important to provide basic antimicrobial and antifungal activity on strains which occur naturally in agrosystems as well as to study their possible cytotoxicity on SH-SY5Y cells, considered as a model of neuronal cells, to evaluate their possible effects on human health. Finally, it was also important to test generally their antioxidant and cytotoxic activity to widen the knowledge about the influence of the EO-thymol chemotype.

\section{Results}

\subsection{GC-MS Analyzes}

Analyzes of commercially-available EO of $O$. vulgare L. allowed the identification of 42 components which presented $96.4 \%$ of total identified components (Table 1 ). The highest quantity reached thymol $(76.0 \%)$. Among the main compounds, we also identified p-cymene (5.7\%), carvacrol (3.2\%), linalool $(2.6 \%)$, and $\gamma$-terpinene $(2.5 \%)$. Based on the dominance of thymol, the tested oregano $\mathrm{EO}$ is thymol chemotype.

Table 1. Identified components in Origanum vulgare EO.

\begin{tabular}{|c|c|c|c|c|c|c|}
\hline No. & $\begin{array}{l}\text { Name of } \\
\text { Compound }\end{array}$ & $\mathrm{KI}^{\exp }$ & $\mathrm{KI}^{\text {lit }}$ & $\%$ & Identif. & \\
\hline 1. & $\alpha$-pinene & 938 & 936 & 0.2 & KI, MS, S & M \\
\hline 2. & camphene & 951 & 950 & 0.2 & KI, MS & M \\
\hline 3. & sabinene & 976 & 973 & 0.1 & KI, MS & M \\
\hline 4. & $\beta$-pinene & 980 & 978 & 0.3 & $\mathrm{KI}, \mathrm{MS}, \mathrm{S}$ & M \\
\hline 5. & $\alpha$-terpinene & 1016 & 1013 & 0.7 & KI, MS, S & M \\
\hline 6. & p-cymene & 1020 & 1015 & 5.7 & KI, MS, S & M \\
\hline 7. & 1,8-cineole & 1033 & 1024 & 0.6 & KI, MS, S & $\mathrm{MO}$ \\
\hline 8. & $(Z)-\beta$-ocimene & 1035 & 1029 & $\mathrm{~T}$ & $\mathrm{KI}, \mathrm{MS}, \mathrm{S}$ & M \\
\hline 9. & $\gamma$-terpinene & 1060 & 1051 & 2.5 & KI, MS, S & M \\
\hline 10. & terpinolene & 1088 & 1082 & $\mathrm{~T}$ & KI, MS, S & M \\
\hline 11. & linalool & 1098 & 1086 & 2.6 & KI, MS, S & $\mathrm{MO}$ \\
\hline 12. & camphor & 1121 & 1123 & 0.7 & $\mathrm{KI}, \mathrm{MS}, \mathrm{S}$ & $\mathrm{MO}$ \\
\hline 13. & L-trans-pinocarveol & 1130 & 1125 & $\mathrm{~T}$ & $\mathrm{KI}, \mathrm{MS}$ & $\mathrm{MO}$ \\
\hline 14. & borneol & 1152 & 1150 & 0.8 & KI, MS, S & $\mathrm{MO}$ \\
\hline 15. & terpinen-4-ol & 1160 & 1164 & 0.7 & KI, MS & $\mathrm{MO}$ \\
\hline 16. & $\alpha$-terpineol & 1178 & 1176 & 0.4 & $\mathrm{KI}, \mathrm{MS}$ & $\mathrm{MO}$ \\
\hline 17. & carvone & 1217 & 1214 & $\mathrm{~T}$ & $\mathrm{KI}, \mathrm{MS}, \mathrm{S}$ & $\mathrm{MO}$ \\
\hline 18. & carvotanacetone & 1230 & 1220 & $\mathrm{~T}$ & $\mathrm{KI}, \mathrm{MS}$ & $\mathrm{MO}$ \\
\hline 19. & thymol & 1270 & 1267 & 76.0 & KI, MS, S & $\mathrm{MO}$ \\
\hline 20. & carvacrol & 1282 & 1278 & 3.2 & $\mathrm{KI}, \mathrm{MS}, \mathrm{S}$ & $\mathrm{MO}$ \\
\hline 21. & eugenol & 1333 & 1331 & 0.1 & KI, MS & $\mathrm{MO}$ \\
\hline 22. & $\alpha$-cubebene & 1354 & 1355 & 0.3 & KI, MS & $S$ \\
\hline 23. & $\alpha$-gurjunene & 1411 & 1413 & $\mathrm{~T}$ & $\mathrm{KI}, \mathrm{MS}$ & $S$ \\
\hline 24. & $\alpha$-himachalene & 1449 & 1450 & 0.1 & KI, MS & S \\
\hline 25. & humulene & 1454 & 1455 & $\mathrm{~T}$ & $\mathrm{KI}, \mathrm{MS}$ & S \\
\hline 26. & allo-aromadendrene & 1461 & 1462 & $\mathrm{~T}$ & $\mathrm{KI}, \mathrm{MS}$ & $S$ \\
\hline 27. & $\beta$-guaiene & 1490 & 1488 & $\mathrm{~T}$ & $\mathrm{KI}, \mathrm{MS}$ & $S$ \\
\hline 28. & valencene & 1494 & 1494 & 0.1 & KI, MS & S \\
\hline 29. & $\alpha$-muurolene & 1495 & 1496 & $\mathrm{~T}$ & $\mathrm{KI}, \mathrm{MS}$ & $S$ \\
\hline 30. & $\gamma$-cadinene & 1512 & 1507 & 0.1 & $\mathrm{KI}, \mathrm{MS}$ & $S$ \\
\hline
\end{tabular}


Table 1. Cont.

\begin{tabular}{|c|c|c|c|c|c|c|}
\hline No. & $\begin{array}{l}\text { Name of } \\
\text { Compound }\end{array}$ & $\mathrm{KI}^{\exp }$ & $\mathrm{KI}^{\text {lit }}$ & $\%$ & Identif. & \\
\hline 31. & calamenene & 1513 & 1517 & $\mathrm{~T}$ & KI, MS & $S$ \\
\hline 32. & $\beta$-cadinene & 1520 & 1526 & 0.4 & KI, MS & $S$ \\
\hline 33. & $\alpha$-calacorene & 1534 & 1527 & 0.1 & KI, MS & $S$ \\
\hline 34. & elemol & 1539 & 1541 & $\mathrm{~T}$ & KI, MS & SO \\
\hline 35. & $\begin{array}{l}\text { caryophyllene } \\
\text { oxide }\end{array}$ & 1580 & 1578 & 0.4 & KI, MS & $\mathrm{SO}$ \\
\hline 36. & globulol & 1583 & 1589 & $\mathrm{~T}$ & KI, MS & $\mathrm{SO}$ \\
\hline 37. & cedrol & 1598 & 1603 & $\mathrm{~T}$ & KI, MS & SO \\
\hline 38. & $\gamma$-eudesmol & 1620 & 1618 & $\mathrm{~T}$ & KI, MS & $\mathrm{SO}$ \\
\hline 39. & $\begin{array}{l}\text { allo-aromadendrene } \\
\text { epoxide }\end{array}$ & 1621 & 1623 & 0.1 & KI, MS & $\mathrm{SO}$ \\
\hline 40. & tau.cadinol & 1634 & 1633 & $\mathrm{~T}$ & KI, MS & $\mathrm{SO}$ \\
\hline 41. & tau.muurolol & 1635 & 1633 & $\mathrm{~T}$ & KI, MS & SO \\
\hline 42. & cubenol & 1636 & 1630 & $\mathrm{~T}$ & KI, MS & SO \\
\hline
\end{tabular}

$\mathrm{T}$-traces less than $0.1 \%$; $\mathrm{KI}^{\mathrm{exp}}$-expected Kovats index predicted by software, $\mathrm{KI}^{\mathrm{lit}}$-comparison of Kovats index with literature (Adams; Hochmuth); Identification:, MS - comparison of mass spectra with the literature, $\mathrm{S}$-comparison with external standard, $\mathrm{M}-$ monoterpenes, $\mathrm{MO}$-oxygenated monoterpenes, S-sesquiterpenes, $\mathrm{SO} —$ oxygenated sesquiterpenes.

\subsection{Phytotoxic Activity}

\subsubsection{Germination}

The influence of different doses of oregano EO on the seed germination of two dicot species (Sinapis alba and Lepidium sativum) and two monocot species (Hordeum vulgare and Triticum aestivum) was investigated (Table 2). The total number of evaluated seeds for each species was 30 , made as a triplication of ten seeds in one petri dish. In general, the number of germinated seeds decreased with the increase of the applied EO dose. The highest number of germinated seeds of $S$. alba was 27 seeds after application, the two lowest EO doses $(0.125$ and $0.0625 \mu \mathrm{g} / \mathrm{mL})$ was 22 seeds after the application of the highest dose EO $(100 \mu \mathrm{g} / \mathrm{mL})$. The lowest number of seeds was 21 , evaluated after application of EO dose $2.5 \mu \mathrm{g} / \mathrm{mL}$. In the control sample were 23 germinated seeds. After application of seven doses of EO $(0.0625 ; 0.125 ; 0.25 ; 1.25 ; 5.0 ; 10.0$, and $50.0 \mu \mathrm{g} / \mathrm{mL})$, the number of germinated seeds was higher in comparison to the control, and after application of three doses $(0.625 ; 2.5 ; 25.0$, and $100 \mu \mathrm{g} / \mathrm{mL})$ the number of germinated seeds was lower in comparison to the control.

The highest number of germinated seeds of L. sativum was 30 seeds, after application of the seven lowest EO doses $(0.0625-5.0 \mu \mathrm{g} / \mathrm{mL})$, which was also a higher number compared to the control. The lowest number of seeds was 27, evaluated after application of EO doses 10, 20, and $50 \mu \mathrm{g} / \mathrm{mL}$, and 28 seeds after application of EO dose $100 \mu \mathrm{g} / \mathrm{mL}$. Twenty-nine seeds were germinated in the control sample.

The highest number of germinated seeds of $H$. vulgare was 22 seeds after application of EO of dose $25 \mu \mathrm{g} / \mathrm{mL}$. The lowest number of germinated seeds was 6 after application of the lowest EO dose $0.0625 \mu \mathrm{g} / \mathrm{mL}$. In the control sample, 17 seeds were germinated. In five doses of EO $(25 ; 10 ; 2.5 ; 1.25$, and $0.25 \mu \mathrm{g} / \mathrm{mL}$ ), the number of germinated seeds was higher compared to the control, and in six doses $(100,50,5,0.625,0.125$, and $0.0625 \mu \mathrm{g} / \mathrm{mL})$ the number of germinated seeds was lower compared to the control.

The highest number of germinated seeds of T. aestivum was 24 seeds after application of EO of dose $1.25 \mu \mathrm{g} / \mathrm{mL}$. The lowest number of germinated seeds was 18 after application of EO with dose 0.625 and $0.25 \mu \mathrm{g} / \mathrm{mL}$. In the control sample, 18 seeds were germinated. After application of all EO doses, the number of germinated seeds was the same or higher than in control sample. 
Slight stimulation, as well as an inhibition effect, was noted in different doses. No significant effect of oregano EO-influenced germination of four species was confirmed.

Table 2. Total number and \% of germinated seed of model organisms in comparison to control after exposition to particular doses of Origanum vulgare EO.

\begin{tabular}{|c|c|c|c|c|c|c|c|c|c|c|c|c|}
\hline & \multicolumn{12}{|c|}{ Applied Doses of EO $(\mu \mathrm{g} / \mathrm{mL})$} \\
\hline & Control & 100 & 50 & 25 & 10 & 5 & 2.5 & 1.25 & 0.625 & 0.25 & 0.125 & 0.0625 \\
\hline \multicolumn{13}{|c|}{ Sinapis alba } \\
\hline Numb. GS & 23 & 22 & 23 & 22 & 25 & 24 & 21 & 24 & 22 & 23 & 27 & 27 \\
\hline$\%$ GS & 76.67 & 73.33 & 76.67 & 73.33 & 83.33 & 80.00 & 70.00 & 80.00 & 73.33 & 76.67 & 90.00 & 90.00 \\
\hline \multicolumn{13}{|c|}{ Lepidium sativum } \\
\hline Numb. GS & 29 & 28 & 27 & 27 & 27 & 30 & 29 & 29 & 30 & 30 & 30 & 30 \\
\hline$\%$ GS & 96.67 & 93.33 & 90.00 & 90.00 & 90.00 & 100 & 96.67 & 96.67 & 100 & 100 & 100 & 100 \\
\hline \multicolumn{13}{|c|}{ Hordeum vulgare } \\
\hline Numb. GS & 17 & 9 & 13 & 22 & 17 & 16 & 19 & 17 & 16 & 19 & 13 & 6 \\
\hline$\%$ GS & 56.67 & 30.00 & 43.33 & 73.33 & 56.67 & 53.33 & 63.33 & 56.67 & 53.33 & 63.33 & 43.33 & 53.33 \\
\hline \multicolumn{13}{|c|}{ Triticum aestivum } \\
\hline Numb. GS & 18 & 19 & 23 & 23 & 22 & 22 & 22 & 24 & 18 & 18 & 23 & 21 \\
\hline$\%$ GS & 60 & 63.33 & 76.67 & 76.67 & 73.33 & 73.33 & 73.33 & 80.00 & 60.00 & 60.00 & 76.67 & 70.00 \\
\hline
\end{tabular}

Numb. GS—number of germinated seeds; \% GS—-percentage of germinated seeds; table squares highlighted by lighter grey indicate lower number $\%$ of germinated seeds, highlighted by darker grey indicate higher number $\%$ of germinated seeds in comparison to control. Total number of treated seeds was 30. Each treatment was triplicated.

\subsubsection{Root Length}

The influence of different doses of oregano EO on root elongation of two dicot species (S. alba and L. sativum) and two monocot species (H. vulgare and T. aestivum) was investigated. Sensitivity with an inhibition effect by oregano EO was noted to be higher in monocot species in comparison to dicot species (Table 3). After application of ten doses of origanum EO on Sinapis alba, we noted longer root length $(1.8-3.2 \mathrm{~cm})$ than in the control sample, and in six of them $(100-5 \mu \mathrm{g} / \mathrm{mL}$ and $0.0625 \mu \mathrm{g} / \mathrm{mL})$ there were significant differences. The dose of $2.5 \mu \mathrm{g} / \mathrm{mL}$ was the only dose where roots were shorter $(1.2 \mathrm{~cm})$ in comparison with the control $(1.5 \mathrm{~cm})$. In this case, the influence of EO was not significant. A similar observation was noted after the application of different doses of oregano EO on seeds of $L$. sativum. From the lowest dose $(0.0625 \mu \mathrm{g} / \mathrm{mL})$ to the second highest $(50 \mu \mathrm{g} / \mathrm{mL})$, the roots were longer $(7.2-9.0 \mathrm{~cm})$ than in the control sample $(4.9 \mathrm{~cm})$. Except for one dose $(10 \mu \mathrm{g} / \mathrm{mL})$, the influence of EO was significant. The highest dose $(100 \mu \mathrm{g} / \mathrm{mL})$ influenced root length negatively $(3.6 \mathrm{~cm})$ with statistical significance. The opposite effect was noted in monocot species, where after the application of eight doses of EO $(100-25 \mu \mathrm{g} / \mathrm{mL}$ and $1.25-0.0625 \mu \mathrm{g} / \mathrm{mL})$ on $H$. vulgare seeds, an inhibition effect was noted, and in six doses was significant. In three doses root lengths were slightly higher $(3.3-3.5 \mathrm{~cm})$ compared to the control $(3.2 \mathrm{~cm})$, but without statistical significance. The effect of oregano EO on T. aestivum root length was very similar to the other monocot species $H$. vulgare. Except for one dose $(5 \mu \mathrm{g} / \mathrm{mL})$, the root length was lower $(1.1-2.5 \mathrm{~cm})$ compared to the control $(2.6 \mathrm{~cm})$, and in six doses there were significant differences.

Generally, a significant stimulation effect of oregano EO was noted in dicot species L. sativum. A significant inhibition effect of oregano EO was noted in three species (L. sativum, H. vulgare, and T. aestivum), at the highest dose. The same dose $(100 \mu \mathrm{g} / \mathrm{mL})$ was significantly stimulative on S. alba. A significant stimulation effect on root elongation in dicot species was noted in four tested doses $(50 \mu \mathrm{g} / \mathrm{mL}, 25 \mu \mathrm{g} / \mathrm{mL}, 5 \mu \mathrm{g} / \mathrm{mL}$, and $0.0625 \mu \mathrm{g} / \mathrm{mL})$. A significant inhibition effect on monocot species was evaluated in five different doses $(100 \mu \mathrm{g} / \mathrm{mL}, 25 \mu \mathrm{g} / \mathrm{mL}, 1.25 \mu \mathrm{g} / \mathrm{mL}, 0.125 \mu \mathrm{g} / \mathrm{mL}$, and $0.0625 \mu \mathrm{g} / \mathrm{mL})$ (Table 3). 
Table 3. Average roots length in $\mathrm{cm}$ of particular model organisms in comparison to control after exposition to different doses of Origanum vulgare EO.

\begin{tabular}{|c|c|c|c|c|c|c|c|c|c|c|c|c|c|}
\hline & & \multicolumn{12}{|c|}{ Applied EO Doses $[\mu \mathrm{g} / \mathrm{mL}]$} \\
\hline & & Cont. & 100 & 50 & 25 & 10 & 5 & 2.5 & 1.25 & 0.625 & 0.25 & 0.125 & 0.0625 \\
\hline \multirow{6}{*}{$\begin{array}{c}\text { Sinapis } \\
\text { alba }\end{array}$} & Min & 0.3 & 0.6 & 0.5 & 0.3 & 0.5 & 0.6 & 0.3 & 0.1 & 0.1 & 0.1 & 0.1 & 0.1 \\
\hline & Max & 3.9 & 7.2 & 6.5 & 10.1 & 6.1 & 10.6 & 5.7 & 5.4 & 4.6 & 4.3 & 5.5 & 5.5 \\
\hline & Mean & 1.5 & 3.2 & 3.1 & 3.4 & 3.2 & 2.8 & 2.3 & 1.9 & 1.8 & 1.2 & 1.8 & 2.3 \\
\hline & SD & 0.9 & 1.9 & 1.9 & 2.8 & 1.6 & 2.3 & 1.8 & 1.6 & 1.5 & 1.1 & 1.6 & 1.6 \\
\hline & Median & 1.3 & 3.3 & 2.8 & 2.5 & 3.1 & 2.1 & 1.6 & 1.9 & 1.2 & 0.7 & 1.2 & 2.5 \\
\hline & Signif. & & $* * *$ & $* * *$ & $* *$ & $* * *$ & $* *$ & & & & & & * \\
\hline \multirow{6}{*}{$\begin{array}{l}\text { Lepidium } \\
\text { sativum }\end{array}$} & Min & 0.3 & 0.5 & 2.1 & 1.8 & 0.5 & 0.6 & 0.5 & 0.2 & 0.3 & 0.4 & 0.5 & 1.5 \\
\hline & Max & 9.6 & 5.8 & 11.2 & 13.2 & 13.1 & 12.0 & 13.1 & 12.8 & 12.5 & 13.0 & 11.0 & 12.3 \\
\hline & Mean & 4.9 & 3.6 & 7.5 & 9.0 & 5.7 & 8.4 & 7.2 & 8.2 & 8.3 & 7.9 & 7.1 & 7.6 \\
\hline & SD & 2.4 & 1.3 & 2.3 & 3.3 & 3.6 & 3.7 & 3.5 & 3.2 & 3.5 & 3.7 & 2.6 & 2.7 \\
\hline & Median & 5.5 & 4.0 & 8.1 & 10.3 & 5.3 & 10.2 & 8.3 & 8.6 & 9.0 & 9.0 & 7.8 & 8.1 \\
\hline & Signif. & & $*$ & $* * *$ & $* * *$ & & $* * * *$ & $* *$ & $* * *$ & $* * *$ & $* * *$ & $* * *$ & $* * *$ \\
\hline \multirow{6}{*}{$\begin{array}{c}\text { Hordeum } \\
\text { vulgare }\end{array}$} & Min & 1.6 & 0.6 & 0.7 & 0.1 & 0.4 & 0.4 & 0.6 & 0.3 & 0.3 & 0.4 & 0.3 & 0.5 \\
\hline & Max & 4.7 & 3.1 & 6.3 & 4.6 & 6.3 & 5.3 & 5.7 & 3.5 & 4.0 & 6.8 & 4.3 & 3.4 \\
\hline & Mean & 3.2 & 1.9 & 3.2 & 1.8 & 3.3 & 3.4 & 3.5 & 1.9 & 1.9 & 2.8 & 2.4 & 2.1 \\
\hline & SD & 0.9 & 0.8 & 1.8 & 1.5 & 1.8 & 1.3 & 1.7 & 1.0 & 1.1 & 1.7 & 1.3 & 0.8 \\
\hline & Median & 3.3 & 2.1 & 3.5 & 1.7 & 3.4 & 3.5 & 3.7 & 2.0 & 1.7 & 2.7 & 2.3 & 2.1 \\
\hline & Signif. & & $* *$ & & ** & & & & $* * *$ & $* * *$ & & $*$ & $* * *$ \\
\hline \multirow{6}{*}{$\begin{array}{l}\text { Triticum } \\
\text { aestivum }\end{array}$} & Min & 0.4 & 0.2 & 0.5 & 0.3 & 0.2 & 0.9 & 1.1 & 0.3 & 0.3 & 1.5 & 0.3 & 0.5 \\
\hline & Max & 3.9 & 1.8 & 3.2 & 2.7 & 3.8 & 4.8 & 4.0 & 2.40 & 3.2 & 3.5 & 2.5 & 3.2 \\
\hline & Mean & 2.6 & 1.1 & 1.9 & 1.7 & 1.9 & 2.8 & 2.5 & 1.7 & 1.9 & 2.4 & 1.5 & 1.8 \\
\hline & SD & 0.9 & 0.5 & 0.8 & 0.6 & 1.1 & 0.8 & 0.9 & 0.5 & 0.9 & 0.6 & 0.6 & 0.7 \\
\hline & Median & 2.8 & 1.2 & 1.8 & 1.8 & 1.9 & 2.9 & 2.8 & 1.9 & 2.0 & 2.3 & 1.5 & 1.8 \\
\hline & Signif. & & $* * *$ & * & $* *$ & & & & $* * *$ & & & $* * *$ & $* *$ \\
\hline
\end{tabular}

Table square highlighted by lighter grey indicates shorter average roots length in comparison to control, highlighted by darker grey indicates higher average roots length in comparison to control. ${ }^{*}-p<0.05,{ }^{* *}-p<0.01,{ }^{* * *}-p<0.001$. Each treatment was triplicated.

\subsection{Cytotoxic Activity}

MTT assay is the most applied method for screening new drugs, either from natural or synthesis origin [33] and it is based on the reduction of MTT due to NADPH-dependent cellular oxidoreductase enzymes. Live cells reduced MTT to formazan while the dead or inactive cells are not capable to do this [34]. $\mathrm{IC}_{50}$ defined as dose of EO required to reduce the cell viability by $50 \%$ [35].

$O$. vulgare $\mathrm{EO}$ was evaluated for its possible cytotoxic activity on human neuroblastoma cell line $(\mathrm{SH}-\mathrm{SY} 5 \mathrm{Y})$ and showed an $\mathrm{IC}_{50}=50.5 \mu \mathrm{g} / \mathrm{mL}$ (Figure 1).

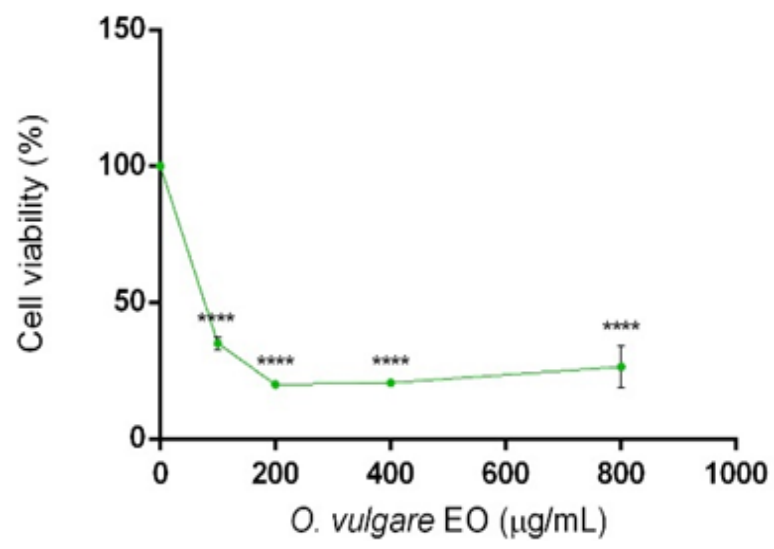

Figure 1. Percentage of cell viability after 3-(4,5-dimethylthiazol-2-yl)-2,5-diphenyl tetrazolium bromide (MTT) assay. Cells were treated with different doses $(800-100 \mu \mathrm{g} / \mathrm{mL})$ of Origanum vulgare EO for $24 \mathrm{~h}$ and solvent (DMSO, $0.1 \%$ ) alone. Data are the mean \pm SD of three experiments ${ }^{* * * *}-p<0.0001$. 


\subsection{In Vitro Antibacterial Effect}

The studied oregano EO showed a promising antibacterial effect on four tested phytopathogenic bacteria in a dose-dependent manner compared to the control (Figure 2). In particular, P. syringae pv. phaseolicola was inhibited completely by all tested doses of oregano EO. P. savastanoi and X. campestris were inhibited only with the highest tested dose (10,000 ppm).

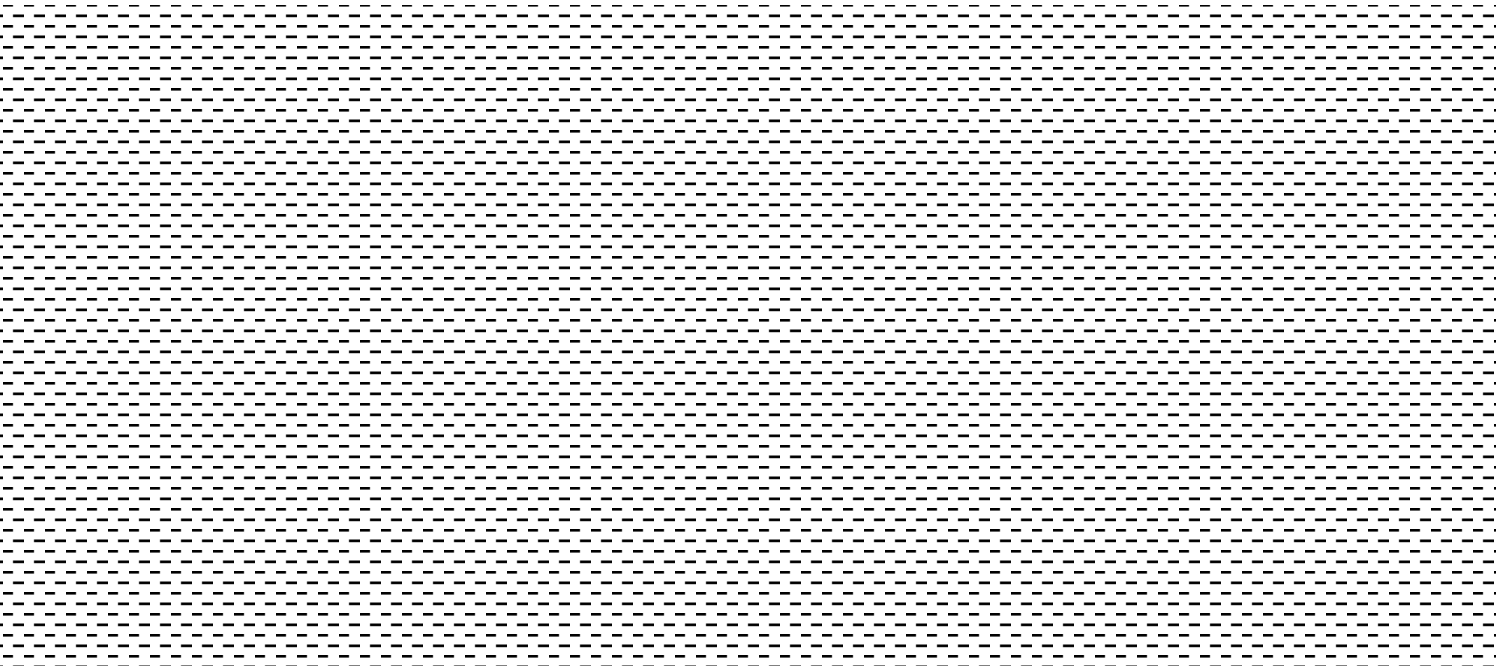

Figure 2. Antibacterial activity of Origanum vulgare EO Bars with different letters for each tested EO dose indicate mean values significantly different at $p<0.05$ according to Tukey (B) test. Data are expressed as mean of three replicates \pm SD.

\subsection{In Vitro Antifungal Effect}

Results showed that all tested doses of oregano EO were able to inhibit the growth of phytopathogenic fungi (Monilinia fructicola (G.Winter) Honey, A. niger, P. expansum, and B. cinerea) (Figure 3). In particular, the highest inhibition activity was observed in the case of 1000 and 500 ppm against the 4 tested fungi. Whereas, the other 2 tested doses (100 and 50 ppm) showed moderate activity in a dose dependent manner (Figure 3).

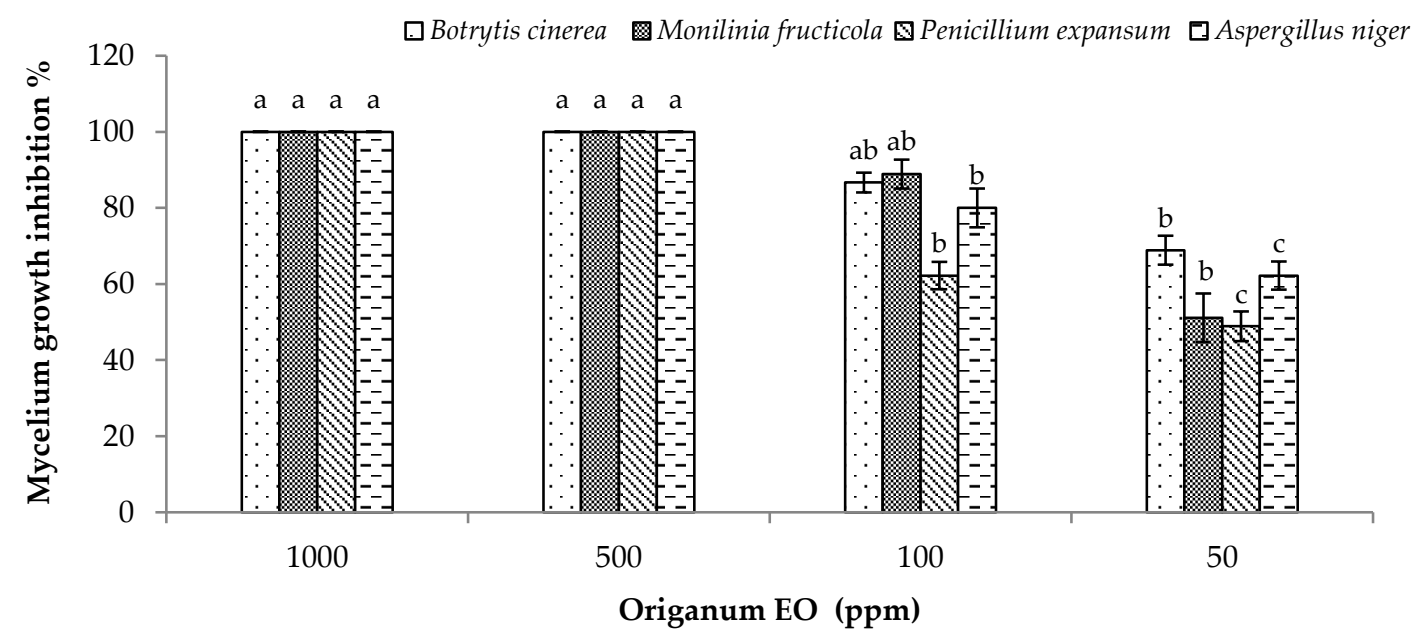

Figure 3. Antifungal activity of Origanum vulgare EO. Bars with different letters for each tested fungus indicate mean values significantly different at $p<0.05$ according to Tukey B test. Data are expressed as mean of three replicates \pm SD. 


\subsection{Free Radical-Scavenging Capacity}

Anti-radical scavenging activity was tested by the 2.2-diphenyl-1-picrylhydrazil (DPPH) model system and expressed as absolute percentage of DPPH remaining in solution. In its radical form, $\mathrm{DPPH}$ has an absorption band at $515 \mathrm{~nm}$, which disappears upon reduction by an antiradical compound. The absorbance of DPPH without the antioxidant (control sample) was used as the baseline measurement. The scavenging activity was expressed as the half maximal effective dose $\left(\mathrm{EC}_{50}\right)$ of the sample, in terms of $\mu \mathrm{g} / \mathrm{mL}$, necessary to inhibit the DPPH radical activity by $50 \%$.

In Table 4, several doses of $O$. vulgare $\mathrm{EO}$ were reported, at three incubation times.

Table 4. Antioxidant activity of different doses of Origanum vulgare EO. Data are reported as mean \pm SD of three replicates. DPPH: 2.2-diphenyl-1-picrylhydrazil.

\begin{tabular}{cccccc}
\hline Sample/Extract & $(\mu \mathrm{g} / \mathrm{mL})$ & $\mathbf{L o g}(\mu \mathrm{g} / \mathbf{m L})$ & $\begin{array}{c}\text { DPPH (\%) } \\
\text { after 15 min }\end{array}$ & $\begin{array}{c}\text { DPPH (\%) } \\
\text { after 30 min }\end{array}$ & $\begin{array}{c}\text { DPPH (\%) } \\
\text { after 45 min }\end{array}$ \\
\hline CTRL DPPH & & & $100 \pm 2.00$ & $100 \pm 2.84$ & $100.00 \pm 3.10$ \\
Oregano & 3 & 0.477 & $97.61 \pm 0.40$ & $96.75 \pm 0.74$ & $95.47 \pm 0.92$ \\
Oregano & 6 & 0.778 & $88.70 \pm 1.34$ & $88.20 \pm 1.57$ & $87.20 \pm 1.69^{* * *}$ \\
Oregano & 12.5 & 1.097 & $92.31 \pm 0.54$ & $89.67 \pm 0.53$ & $87.41 \pm 0.79^{* * *}$ \\
Oregano & 25 & 1.398 & $86.22 \pm 0.86^{*}$ & $82.42 \pm 1.35^{* *}$ & $79.06 \pm 1.66^{* * * *}$ \\
Oregano & 50 & 1.699 & $83.52 \pm 8.14^{* * * *}$ & $72.64 \pm 3.23^{* * * *}$ & $68.00 \pm 3.15^{* * * *}$ \\
Oregano & 100 & 2.000 & $69.59 \pm 4.72^{* * * *}$ & $58.14 \pm 4.46^{* * * *}$ & $52.84 \pm 4.30^{* * * *}$ \\
Oregano & 200 & 2.301 & $46.66 \pm 5.07^{* * * *}$ & $38.89 \pm 4.45^{* * * *}$ & $33.80 \pm 3.96^{* * * *}$
\end{tabular}

${ }^{*}-p<0.05,{ }^{* *}-p<0.01,{ }^{* * *}-p<0.001,{ }^{* * * *}-p<0.0001$. Values followed by different stars are significant according to Tukey's multiple comparisons test.

From statistical analysis, O. vulgare EO showed an $\mathrm{IC}_{50}=192.3 \mu \mathrm{g} / \mathrm{mL}$ after 15 min, $\mathrm{IC}_{50}=134.9 \mu \mathrm{g} / \mathrm{mL}$ after $30 \mathrm{~min}$ and $\mathrm{IC}_{50}=106.6 \mu \mathrm{g} / \mathrm{mL}$ after $45 \mathrm{~min}$ (Figure 4$)$.

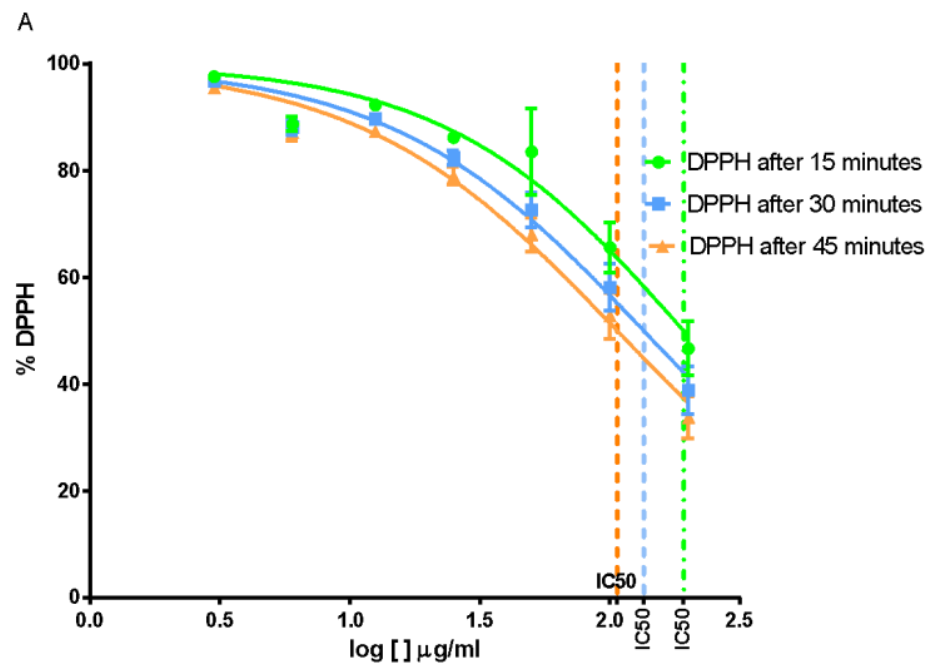

Figure 4. Percentage of DPPH in solution after 15, 30, and 45 min of treatment with different doses of Origanum vulgare EO.

\section{Discussion}

In the studies where oregano EO was tested on its phytotoxic activity, we have noted different species of oregano as well as different chemotypes. The relative species analyzed were O. heracleoticum with its high content of carvacrol (77.8\%), O. majorana with the chemical composition of dominant components terpinen-4-ol 29.6\%, $\delta$-2-carene 20\%, and camphene $13 \%$ [5], O. onites and O. acutidens with their high content of carvacrol $(66 \%$ and $87 \%)$ [27,36]. High content of carvacrol $(84 \%)$ was also 
evaluated in oregano hybrid: O. vulgare L. ssp. virilidum x O. vulgare L. ssp. hirtum (Link) Iestwart [37], which was tested on phototoxic activity. Two scientific works have published the results of phytotoxic activity of O. vulgare ssp. hirtum L. where the dominant compounds were identified in the first case as o-cymene $19.8 \%$, thymol $27 \%$, and carvacrol $19 \%$ [8], and in a second study as 1,8 cineol $36 \%$ and camphor $17 \%$ [36]. Compared to other studies which focused on the same species as our experiment (O. vulgare), the dominant compounds were identified as (1) (carvacrol 44\% and p-cymene 42\%) [38]; (2) carvacrol (34.0\%), $\gamma$-terpinene (21.6\%), and p-cymene (9.4\%) [29], and unspecified species of Origanum (3) carvacrol (60\%), p-cymene (15.5), and $\gamma$-terpinene (5\%) [39]. In only one study the EO of O. vulgare had thymol (50.41\%) as dominant compound, following by carvacrol (12.96\%), 2-bornene (11.28\%), z-terpinen (8.80\%), and o-cymene (6.68\%) [29]. In the commercial sample of 0. vulgare was identified dominant compound thymol with the amount of $76 \%$. The chemical composition of the present sample differs from others EO in previous similar studies.

The design of published studies is slightly different but basically used similar principles. All studies focused of testing the phytotoxic activities on dicot model plant species and the results showed strong activity in each of these studies, although different EO doses were used. The herbicidal effect was evaluated on seed germination as well as on root length respective to seedling development $[5,8,27,28,36,38]$.

The only previous study evaluated the potential herbicidal effects of $O$. onites and O. vulgare ssp. hirtum EO against monocot plant species (Echinochloa crus-galli and Oryza sativa) compared to the other tested plant species; both monocot species were less sensitive [36]. The molecular structure of each component can be responsible for the specific MOA as was previously mentioned [9]. Developing a selective herbicide, even if some data are promising, is difficult in the moment. It is well known that the major problem with EO is its volatility. The final formulation of the product is therefore of almost importance. One solution of the volatility problem could be the controlled release by using encapsulation. Encapsulation conserves and protects EOs from outside aggression, which is useful for applications in agronomy [32].

It is known that many herbicides, such as glyphosate, are associated with a cytotoxic and demyelinating effects [40]. In addition, several pesticides such as organophosphates, carbamates, and organochlorine have a direct effect on nervous system [6]. For this reason, our current research has also evaluated the possible cytotoxic effect of $O$. vulgare EO against Central Nervous System using SH-SY5Y cells.

We obtained promising results, for the first time, for O. vulgare EO from Slovakia origin against the SH-SY5Y cell line. Other O. vulgare EOs from different origins such as Jordan, Chile, and Italy showed less activity against other tumor cell lines such as adenocarcinoma (MCF7), human colon adenocarcinoma (HT-29), and human hepatocellular carcinoma (HepG2) cell lines, respectively [23,41,42]. In fact, after incubation for $72 \mathrm{~h} \mathrm{O}$. vulgare EO from Jordan showed $\mathrm{IC}_{50}=30.1 \mu \mathrm{g} / \mathrm{mL}$ against MCF7 cells [34]. After $72 \mathrm{~h}$, the percentage of HT-29 cell growth inhibition was $60.8 \%$ at a dose of $50 \mathrm{mg} / \mathrm{mL}$ of EO from Chile [35]; in this study, a treatment of $100 \mu \mathrm{g} / \mathrm{mL}$ in SH-SY5Y cells for $24 \mathrm{~h}$ showed an inhibition of $64.9 \%$. The antiproliferative activity of $O$. vulgare EO was tested also in HepG2 cell with an $\mathrm{IC}_{50}$ of $236 \mu \mathrm{g} / \mu \mathrm{L}$ at an amount 50-times greater than our results [21]. However, our $\mathrm{IC}_{50}$ values and those reported in previous studies indicated that $\mathrm{O}$. vulgare $\mathrm{EO}$ is not cytotoxic as judged by the criterion set by the National Cancer Institute, because its $\mathrm{IC}_{50}$ is $<20 \mu \mathrm{g} / \mathrm{mL}$ [43].

The antibacterial activity of the EOs is dependent on the composition and dose of the EO, the type and dose of the target microorganism [44]. Oregano EO showed promising antibacterial, antifungal, and antiviral activities against several phytopathogens [11,25]. The antimicrobial activity can be explained by the chemical composition of phenolic compound present in oregano [24]. In particular, carvacrol and thymol are phenolic compounds with similar structures previously showed antifungal activity against many pathogenic fungi $[5,25]$. These phenolic compounds have a lipophilic character, acting in the cell wall and interfering with membrane-catalyzed enzymes and with enzymes responsible for energy and protein production, causing cell death [11,24]. Several studies have focused on the bioactive constituents of oregano plant as well as its EO [22-24]. 
When the cell endogenous detoxifying systems are no longer able to scavenge reactive oxygen species (ROS), oxidative stress arises. This stressed condition can damage lipids, proteins, and nucleic acids, leading to irreversible damages and cell death: For this motive, the quantity of ROS inside the cell increases endogenous and exogenous ROS production [45]. The antioxidant properties of $O$. vulgare EO have been extensively investigated using 2.2-diphenyl-1-picrylhydrazil (DPPH) method. A slight antiradical power of oregano EOs with percentage values from $2.85 \%$ to $3.68 \%$, increasing with doses (7-9 mg/mL), was reported [46]. Other researchers have documented a similar low activity with $\mathrm{EC}_{50}$ value of $1509.1 \pm 119.0 \mu \mathrm{g} / \mathrm{mL}$ corresponding to 0.05 antioxidant activity index (AAI) [47]. Higher inhibition activity (93\%) of the synthetic free radical at the highest tested EO dose $(50 \mu \mathrm{L} / \mathrm{mL})$ was obtained by Kačániová et al. [48]. Considerable scavenging activity (59.09\% and 54.8\%) at both tested EO doses (1000 and 100 ppm) was observed [49]. The quite good radical scavenging activity in comparison with data reported in literature could be due to a high percentage of thymol found in this oregano sample: It was reported that the antioxidant activity of thymol alone is $104.44 \mu \mathrm{g} / \mathrm{mL}$ [50].

\section{Materials and Methods}

\subsection{Essential Oil}

The studied EO was obtained from the company Calendula a.s. Slovakia, which is specialized for production variety of EOs for commercial use.

\subsection{Tested Plant Seeds}

Evaluation of potential phytotoxic effect of EO was evaluated on seeds of four species. We chose two dicotyledonous species as Sinapis alba L. (white mustard) and Lepidium sativum L. (garden cress) and two monocotyledonous species Triticum aestivum L. (common wheat) and Hordeum vulgare L. (barley). S. alba and L. sativum L. (cv. 'Dánska') seeds were purchased from Zel Seed (Slovakia). Common wheat and barley were obtained from the Research Center in Malý Šariš (Slovakia).

\subsection{Phytotoxic Assay}

Phytotoxic assay followed the previously used method [25] with slight modifications. Two factors were taken into account in the experimental treatment: (i) Four test plants: (S. alba L., L. sativum L., T. aestivum L., and H. vulgare L.) and (ii) eleven different O. vulgare EO doses: (100-0.062 $\mu \mathrm{g} / \mathrm{mL})$. The tested EOs were dissolved in distilled water/acetone 99.5:0.5 and diluted to prepare the desired doses. Distilled water/acetone 99.5:0.5 was used as a control. Test seeds were surface sterilized in 95\% EtOH for $15 \mathrm{~s}$ and rinsed triplicate in distilled water. Ten sterilized seeds were sown into each Petri dish (90 mm diameter) containing 5 layers of Whatman filter paper. In each Petri dish $7 \mathrm{~mL}$ of EO solutions of different doses or distilled water/acetone 99.5:0.5 was added. Each treatment was triplicated. The Petri dishes were kept in a growth chamber $\left(20 \pm 1^{\circ} \mathrm{C}\right.$, natural photoperiod, Sanyo, MLR-351H). Evaluation of germination and the radicle length $(\mathrm{cm})$ was measured after $120 \mathrm{~h}$.

\subsection{GC/MS Analysis}

Samples of EOs were analyzed by a gas chromatography/mass spectrometry (GC/MS) at University of Prešov (Prešov, Slovakia). The analyses were done by Varian 450-GC gas chromatograph with 220-MS IT Mass Spectrometer (Varian, Inc., CA, USA). Separation of individual components was provided using a capillary column BR $5 \mathrm{~ms}(30 \mathrm{~m} \times 0.25 \mathrm{~mm}$ ID, $0.25 \mu \mathrm{m}$ film thickness; Bruker Daltonics Inc., MA, USA). Injector type 1177 was heated to a temperature of $220^{\circ} \mathrm{C}$. Injection mode was split less ( $1 \mu \mathrm{L}$ of a 1:1000 n-hexane solution). Helium was used as a carrier gas at a constant column flow rate of $1.2 \mathrm{~mL} \mathrm{~min}^{-1}$. Column temperature was programmed in four steps: (1) $50{ }^{\circ} \mathrm{C}$ for $10 \mathrm{~min}$, (2) $100{ }^{\circ} \mathrm{C}$ at $3{ }^{\circ} \mathrm{C} \mathrm{min}^{-1}$, (3) isothermal for $5 \mathrm{~min}$, and (4) $150{ }^{\circ} \mathrm{C}$ at $10{ }^{\circ} \mathrm{C} \mathrm{min}-1$. The total time for analysis was $87.67 \mathrm{~min}$. The MS trap was heated to $200{ }^{\circ} \mathrm{C}$, manifold $50{ }^{\circ} \mathrm{C}$ and transfer line $270{ }^{\circ} \mathrm{C}$. Mass spectra were scanned every $1 \mathrm{~s}$ in the range $40-650 \mathrm{~m} / \mathrm{z}$. The retention indices were 
determined in relation to the Rt values of a homologous series of n-alkanes (C10-C35) under the same operation conditions. Constituents were identified by comparison of their retention indices (RI) with published data in different literature. Further identification was made by comparison of the mass spectra with either those stored in NIST 02 library or with those from the literature [51,52]. Relative doses of components were evaluated as percentage of peak area normalization.

\subsection{Antibacterial Activity}

\subsubsection{Tested Bacteria}

The tested bacteria were C. michiganensis, P. syringae pv. phaseolicola, P. savastanoi, and X. campestris. All bacteria were conserved in the collection of the School of Agricultural, Forestry, Food, and Environmental Sciences (SAFE), Basilicata University, Potenza, Italy.

\subsubsection{Bactericidal Assay}

The antibacterial test of the studied EO was investigated following the disc diffusion method [12,53]. The above tested bacterial strains have been cultured on King B nutrient media (KB) [54]. The bacterial suspensions were prepared in sterile distilled water at $106 \mathrm{CFU} / \mathrm{mL}$ doses. Mixtures of bacterial suspensions in soft agar $(0.7 \%)$ were prepared at $9: 1 ;(v / v)$ and then $4 \mathrm{~mL}$ of this mixture was poured into each Petri dish $(90 \mathrm{~mm})$. Tween $20(0.2 \%)$ was added to each EO mixture to avoid the bacterial cellular aggregation at the following doses: 10000, 1000, 100, and 10 ppm. Four discs (6 mm-OXOID) were placed on the surface of Petri dishes and $15 \mu \mathrm{L}$ from different doses of the studied EO was applied per each disc and the bactericidal effect was evaluated by measuring the diameter of inhibition zone $(\mathrm{mm})$ in comparison to tetracyclin antibiotic $\left(1600 \mu \mathrm{g} \cdot \mathrm{ml}^{-1}\right)$. The growth inhibition percentage (GIP) was calculated using the following Equation (1):

$$
G I P=100-\frac{(G C-G T)}{G C} \times 100
$$

where: GIP represents the bacterial inhibition percentage, GC the average diameter of bacterial grown in plate (control) in $\mathrm{mm}$ and GT the average diameter of inhibition zone in $\mathrm{mm}$. The test was repeated twice with three replicates.

\subsection{Antifungal Activity}

\subsubsection{Tested Fungi}

Four serious post-harvest phytopathogenic fungi (B. cinerea, M. fructicola, A. niger, and P. expansum) were tested for the antifungal activity assay.

\subsubsection{Fungicidal Assay}

The fungicidal activity of the tested oregano EO was evaluated following the methods $[24,55]$ at three different doses 1000, 500, 100, and 50 ppm incorporated directly into Potato Dextrose Agar (PDA) medium at $45^{\circ} \mathrm{C}$. A fresh fungal disk $(\varnothing 0.5 \mathrm{~cm})$ was inoculated in the center of Petri dish. All plates were incubated at $22 \pm 2{ }^{\circ} \mathrm{C}$ for $96 \mathrm{~h}$ under darkness and the diameter of fungal mycelium growth was measured in $\mathrm{mm}$. PDA plates without any treatment were inoculated only with fungal disks as negative control (-ve). Fungi toxic effect was expressed as percentage of mycelium growth inhibition (PGI \%) compared to (-ve) control using the formula [24,56] (Equation (2)):

$$
P G I(\%)=\frac{100 \times(G C-G T)}{G C}
$$

where PGI is the percentage of growth inhibition, GC is the average diameter of fungal mycelium in PDA (Control), and GT is the average diameter of fungal mycelium on the oil-treated PDA dish. 


\subsection{Free Radical-Scavenging Capacity}

The antiradical activity of the EO was determined using the sTable 1,1-diphenyl-2-picrylhydrazyl radical (DPPH), according to the method [57] with some modifications [58]. In its radical form, DPPH has an absorption band at $517 \mathrm{~nm}$, which disappears upon reduction by an antiradical compound. Briefly, an aliquot of the $\mathrm{MeOH}$ solution containing different amounts of the EO was added to a DPPH solution $\left(7.6 \times 10^{-5} \mathrm{M}\right)$, prepared daily, kept in the dark when not used, to have a final volume of $1 \mathrm{~mL}$ in a straight-sided cuvette, optically clear container for holding liquid samples in a spectrophotometer. An equal volume of the DPPH alone was added to control tubes. Absorbance at $515 \mathrm{~nm}$ was measured on Multiskan Spectrum Microplate Spectrophotometer (Thermo Fischer Scientific, Vantaa, Finland) after 15,30 , and $45 \mathrm{~min}$; the doses of the extracts were 3, 6, 12.5, 25, 50, 100, and $200 \mu \mathrm{g} / \mathrm{mL}$. For preparation of the standard curve, different doses of DPPH methanol solutions $(10-60 \mu \mathrm{g} / \mathrm{mL})$ were used. The DPPH dose $(\mu \mathrm{g} / \mathrm{mL})$ in the reaction medium was calculated from the following calibration curve, determined by linear regression (r2: 0.9993):

$$
\text { Absorbance }(\lambda \text { 515) }=0.0008+0.0118 \times[\mathrm{DPPH}]
$$

The scavenging capability of test extracts was calculated using the following equation:

$$
D D P H \text { scavenging activity }(\%)=\frac{100 \times[A(\lambda 515) C-A(\lambda 515) S]}{A(\lambda 515) C}
$$

where $\mathrm{A}(\lambda 515) \mathrm{C}$ is absorbance of a control with no radical scavenger and $\mathrm{A}(\lambda 515) \mathrm{S}$ is absorbance of the remaining DPPH in the presence of scavenger. The IC50 value was defined as the dose of sample which reduced the initial DPPH.

\subsubsection{Ascorbic Acid}

Ascorbic acid (Fluka Buchs, Switzerland) was dissolved in methanol. The solution $(5 \mu \mathrm{g} / \mathrm{mL})$ was used for a calibration curve of DPPH reduction and as a chemical reference in comparison to the antioxidant capacity of the extracts.

\subsubsection{Statistical Analysis}

All experiments were carried out in triplicate. Data of each experiment were statistically analyzed using GraphPad Prism 6.0 software followed by comparison of means (two-way ANOVA) using Tukey's multiple comparisons test, at the significance level of $p<0.05$.

\subsection{Cytotoxic Activity}

\subsubsection{Cell Cultures}

Human neuroblastoma (SH-SY5Y) cancer cells were cultured in Roswell Park Memorial Institute Medium (RPMI) supplemented with 1\% L-glutamine, $10 \%$ heat-inactivated fetal bovine serum (FBS), $1 \%$ penicillin/streptomycin (all from Sigma Aldrich) at $37^{\circ} \mathrm{C}$ in an atmosphere of $95 \% \mathrm{O}_{2}$ and $5 \% \mathrm{CO}_{2}$.

\subsubsection{MTT Assay}

Human neuroblastoma cancer cells (SH-SY5Y) were plated $\left(5 \times 10^{3}\right)$ in 96 -well culture plates in $150 \mu \mathrm{l}$ of culture medium and incubated at $37^{\circ} \mathrm{C}$ in humidified $5 \% \mathrm{CO}_{2}$. The day after, a $150 \mu \mathrm{l}$ aliquot of serial dilutions of EOs $(800-50 \mu \mathrm{g} / \mathrm{mL})$ selected on the basis of our previous studies [59,60], their main component or extracts and their fractions were added to the cells and incubated for $24 \mathrm{~h}$. DMSO alone was used as control. Cell viability was assessed through MTT (3-(4,5-dimethylthiazol-2-yl)-2,5-diphenyl tetrazolium bromide) assay. Briefly, $30 \mu \mathrm{l}$ of MTT $(5 \mathrm{mg} / \mathrm{mL})$ was added and the cells incubated for additional $3 \mathrm{~h}$. Thereafter, cells were lysed and the dark blue crystals solubilized with $30 \mu \mathrm{l}$ of a 
solution containing 50\%, v/v, N,N-dimethylformamide, 20\%, w/v, SDS with an adjusted pH of 4.5. The optical density (OD) of each well was measured with a microplate spectrophotometer (Thermo Scientific Multiskan GO, Monza, Italy) equipped with a $520 \mathrm{~nm}$ filter. Cell viability in response to treatment was calculated as a percentage of control cells treated with DMSO at the final dose of $0.1 \%$ viable cells $=(100 \mathrm{OD}$ treated cells $) / \mathrm{OD}$ control cells modifications [61].

\subsection{Data Analysis}

\subsubsection{Germination Activity}

Germination activity was expressed in total number as well as in average \% of germinated seeds after exposure to particular doses of oregano EO. Student T-test counted in EXCEL was used to test the differences among experiments and control in the \% of germinated seeds. Descriptive Statistic in PAST 2.17c [62] was used to depict distinctions in the germination activity in \% among experiments and control.

\subsubsection{Roots Length}

Minimal, maximal, mean values (+ standard deviation), and median of the root lengths of the control and experimental samples by particular doses of oregano EO were calculated using Univariate statistics in PAST 2.17c [62]. Descriptive Statistic in PAST 2.17c [62] was used to depict distinctions in the root lengths in $\mathrm{cm}$ among experiments and control. Student T-test counted in EXCEL was used to test the differences among experiments and control in the roots' length, as well as to test mutual distinctions in the roots' length among experiments with one another. Student T-test counted in EXCEL was used to test the differences in the number of roots among Hordeum vulgare and control, Triticum aestivum and control as well as Hordeum vulgare and Triticum aestivum each other.

\section{Conclusions}

Germination of all four species was not influenced by EO. Phytotoxic effect was statistically significant in monocot species, while in dicot species the opposite was observed-the stimulation effect, which was also statistically significant. Based on the results we can conclude that EO of O. vulgare presented diverse effects on monocot and dicot plant species in observation of its biological activity.

Author Contributions: Conceptualization and project administration, D.G., V.D.F., J.P., and I.C.; formal analysis, GC/MS analysis, D.G., phytotoxic activity, V.S. and Z.G.; antibacterial and antifungal activity, H.S.E.; cytotoxic activity, L.C., antioxidant activity, L.D.M.; data curation, B.B.; writing original draft preparation, D.G., H.S.E., L.C., and L.D.M.; writing review and editing, I.C., J.P., H.S.E., and V.D.F. All authors have read and agreed to the published version of the manuscript.

Funding: This research was funded by projects: KEGA, grant number 018PU-4/2018 and VEGA grant number 1/0783/18.

Conflicts of Interest: The authors declare no conflict of interest.

\section{References}

1. Duke, S.O. Why have no new herbicide modes of action appeared in recent years? Pest Manag. Sci. 2012, 68, 505-512. [CrossRef] [PubMed]

2. $\quad$ Korres, N.E.; Burgos, N.R.; Travlos, I.; Vurro, M.; Gitsopoulos, T.K.; Varanasi, V.K.; Duke, S.O.; Kudsk, P.; Brabham, C.; Rouse, C.E.; et al. New directions for integrated weed management: Modern technologies, tools and knowledge discovery. Adv. Agron. 2019, 155, 243-319.

3. Dayan, F.E.; Owens, D.K.; Duke, S.O. Rationale for a natural products approach to herbicide discovery. Pest. Manag. Sci. 2012, 68, 519-528. [CrossRef] [PubMed]

4. Gerwick, B.C.; Sparks, T.C. Natural products for pest control: An analysis of their role, value and future. Pest. Manag. Sci. 2014, 70, 1169-1185. [CrossRef] [PubMed] 
5. Della Pepa, T.; Elshafie, H.S.; Capasso, R.; De Feo, V.; Camele, I.; Nazzaro, F.; Scognamiglio, M.R.; Caputo, L. Antimicrobial and phytotoxic activity of Origanum heracleoticum and O. majorana essential oils growing in Cilento (Southern Italy). Molecules 2019, 24, 2576. [CrossRef] [PubMed]

6. Keifer, M.C.; Firestone, J. Neurotoxicity of pesticides. J. Agromed. 2007, 12, 17-25. [CrossRef] [PubMed]

7. Jankowska, M.; Rogalska, J.; Wyszkowska, J.; Stankiewicz, M. Molecular targets for components of essential oils in the insect nervous system-A review. Molecules 2018, 23, 34. [CrossRef]

8. Araniti, F.; Landi, M.; Lupinia, A.; Sunseria, F.; Guidib, L.; Abenavolia, M.R. Origanum vulgare essential oils inhibit glutamate and aspartate metabolism altering the photorespiratory pathway in Arabidopsis thaliana seedlings. J. Plant. Physiol. 2018, 231, 297-309. [CrossRef]

9. Lins, L.; Dal Maso, S.; Foncoux, B.; Kamili, A.; Laurin, Y.; Genva, M.; Jijakli, M.H.; De Clerck, C.; Fauconnier, M.L.; Deleu, M. Insights into the relationships between herbicide activities, molecular structure and membrane interaction of cinnamon and citronella essential oils components. Int. J. Mol. Sci. 2019, 20, 4007. [CrossRef]

10. López, M.D.; Jórdan, J.J.; Pascual-Villalobo, M.J. Toxic compounds in essential oils of coriander, caraway and basil active against stored rice pests. J. Stored Prod. Res. 2008, 44, 273-278. [CrossRef]

11. Elshafie, H.S.; Camele, I. An Overview of the biological effects of some mediterranean essential oils on human health. BioMed Res. Int. 2017, 2017, 1-14. [CrossRef] [PubMed]

12. Elshafie, H.S.; Grul'ová, D.; Baranová, B.; Caputo, L.; De Martino, L.; Sedlák, V.; Camele, I.; De Feo, V. Antimicrobial activity and chemical composition of essential oil extracted from Solidago canadensis L. growing wild in Slovakia. Molecules 2019, 24, 1206. [CrossRef] [PubMed]

13. Arminante, F.; De Falco, E.; De Feo, V.; De Martino, L.; Mancini, E.; Quaranta, E. Allelopathic Activity of Essential Oils from Mediterranean Labiatae. Acta Hort. 2006, 723, 347-356. [CrossRef]

14. Kokkini, S.; Karousou, R.; Hanlidou, E. Herbs of the Labiatae. In Encyclopedia of Food Sciences and Nutrition, 2nd ed.; Caballero, B., Ed.; Academic Press: San Diego, CA, USA, 2003; pp. 3082-3090.

15. Robu, T.; Milică, C. Plante medicinale autohtone; Institutul European: Iaşi, Romania, 2004; p. 308. ISBN 973-611-277-2.

16. Fikry, S.; Khalil, N.; Salama, O. Chemical profiling, biostatic and biocidal dynamics of Origanum vulgare L. essential oil. AMB Express 2019, 9, 41. [CrossRef]

17. Alagawany, M.; Abd El-Hack, M.A.; Farag, M.; Shaheen, H.; Abdel-Latif, M.; Noreldin, A.; Patra, A. The usefulness of oregano and its derivatives in poultry nutrition. World's Poult. Sci. J. 2018, 74, 463-474. [CrossRef]

18. Didry, N.; Dubreuil, L.; Pinkas, M. Antibacterial activity of thymol, carvacrol and cinnamaldehyde alone or in combination. Die Pharm. 1993, 48, 301-304.

19. Lee, C.-J.; Chen, L.-W.; Chen, L.-G.; Chang, T.-L.; Huang, C.-W.; Huang, M.-C.; Wang, C.-C. Correlations of the components of tea tree oil with its antibacterial effects and skin irritation. J. Food Drug Anal. 2013, 21, 169-176. [CrossRef]

20. Magi, G.; Marini, E.; Facinelli, B. Antimicrobial activity of essential oils and carvacrol, and synergy of carvacrol and erythromycin, against clinical, erythromycin-resistant Group A streptococci. Front. Microbiol. 2015, 6, 165. [CrossRef]

21. Sharifi-Rad, M.; Varoni, E.M.; Iriti, M.; Martorell, M.; Setzer, W.N.; Contreras, M.D.M.; Salehi, B.; Soltani-Nejad, A.; Rajabi, S.; Tajbakhsh, M.; et al. Carvacrol and human health: A comprehensive review. Phytother. Res. 2018, 32, 1675-1687. [CrossRef]

22. Kintzios, S. The Genera Origanum and Lippia, 1st ed.; Taylor \& Francis: London, UK, 2004.

23. Elshafie, H.S.; Armentano, M.F.; Carmosino, M.; Bufo, S.A.; De Feo, V.; Camele, I. Cytotoxic activity of Origanum vulgare L. on hepatocellular carcinoma cell line HepG2 and evaluation of its biological activity. Molecules 2017, 22, 1435. [CrossRef]

24. Elshafie, H.S.; Mancini, E.; Sakr, S.; De Martino, L.; Mattia, C.A.; De Feo, V.; Camele, I. Antifungal activity of some constituents of Origanum vulgare L. essential oil against postharvest disease of peach fruit. J. Med. Food 2015, 18, 929-934. [CrossRef] [PubMed]

25. Mancini, E.; Camele, I.; Elshafie, H.S.; De Martino, L.; Pellegrino, C.; Grulova, D.; De Feo, V. Chemical Composition and biological activity of the essential oil of Origanum vulgare ssp. hirtum from different areas in the Southern Apennines (Italy). Chem. Biodivers. 2014, 11, 639-651. [CrossRef] [PubMed]

26. Adebayo, O.; Dang, T.; Bélanger, A.; Khanizadeh, S. Antifungal studies of selected essential oils and a commercial formulation against Botrytis Cinerea. J. Food Res. 2013, 2, 217-226. [CrossRef] 
27. Kordali, S.; Cakir, A.; Özer, H.; Cakmakci, R.; Kesdek, M.; Mete, E. Antifungal, phytotoxic and insecticidal properties of essential oil isolated from Turkish Origanum acutidens and its three components, carvacrol, thymol and p-cymene. Bioresour. Technol. 2008, 99, 8788-8795. [CrossRef]

28. Onaran, A.; Yilar, M.; Belguzar, S.; Bayan, Y.; Aksit, H. Antifungal and bioherbicidal properties of essential oils of Thymus fallax Fish \& Mey. Origanum vulgare L. and Mentha dumetorum Schult. Asian J. Chem. 2014, 26, 5159-5164.

29. Fouad, R.; Bousta, D.; Lalami, A.E.O.; Chahdi, F.O.; Amri, I.; Jamoussi, B.; Greche, H. Chemical composition and herbicidal effects of essential oils of Cymbopogon citratus (DC) Stapf, Eucalyptus cladocalyx, Origanum vulgare L. and Artemisia absinthium L. cultivated in Morocco. J. Essent. Oil Bear. Plants 2015, 18, 112-123. [CrossRef]

30. FAOSTAT. Food and Agriculture Organization of the United Nations, Statistics Division. Forestry Production and Trade. Available online: http://www.fao.org/faostat/en/\#data/FO (accessed on 4 April 2019).

31. Regulation, E.C. Regulation (EC) No 1107/2009 of the European Parliament and of the Council of 21 October 2009. Available online: https://eur-lex.europa.eu/legal-content/EN/TXT/?uri=celex\%3A32009R1107 (accessed on 5 January 2020).

32. Maes, C.; Bouquillon, S.; Fauconnier, M.-L. Encapsulation of essential oils for the development of biosourced pesticides with controlled release: A Review. Molecules 2019, 24, 2539. [CrossRef]

33. Bahuguna, A.; Khan, I.; Bajpai, V.K.; Kang, S.C. MTT assay to evaluate the cytotoxic potential of a drug. Bangladesh J. Pharmacol. 2017, 12, 8. [CrossRef]

34. Berridge, M.V.; Herst, P.M.; Tan, A.S. Tetrazolium dyes as tools in cell biology: New insights into their cellular reduction. Biotechnol. Annu. Rev. 2005, 11, 127-152.

35. Sebaugh, J.L. Guidelines for accurate EC50/IC50 estimation. Pharm. Stat. 2011, 10, 128-134. [CrossRef]

36. Argyropoulos, E.I.; Eleftherohorinos, I.G.; Vokou, D. In vitro evaluation of essential oils from Mediterranean aromatic plants of the lamiaceae for weed control in tomato and cotton crops. Allelopath. J. 2008, 22, 69-78.

37. De Mastro, G.; Fracchiolla, M.; Verdini, L.; Montemurro, P. Oregano and itspotential use as bioherbicide. Acta Hortic. 2006, 723, 335-346. [CrossRef]

38. De Almeida, L.F.R.; Frei, F.; Mancini, E.; De Martino, L.; De Feo, V. Phytotoxic activities of mediterranean essential oils. Molecules 2010, 15, 4309-4323. [CrossRef] [PubMed]

39. Ibáñez, M.D.; Blázquez, M.A. Herbicidal value of essential oils from oregano-like flavour species. Food Agric. Immunol. 2017, 28, 1168-1180. [CrossRef]

40. Szepanowski, F.; Kleinschnitz, C.; Stettner, M. Glyphosate-based herbicide: A risk factor for demyelinating conditions of the peripheral nervous system? Neural Regen. Res. 2019, 14, 2079-2080. [CrossRef]

41. Al-Kalaldeh, J.Z.; Abu-Dahab, R.; Afifi, F.U. Volatile oil composition and antiproliferative activity of Laurus nobilis, Origanum syriacum, Origanum vulgare, and Salvia triloba against human breast adenocarcinoma cells. Nutr. Res. 2010, 30, 271-278. [CrossRef]

42. Begnini, K.R.; Nedel, F.; Lund, R.G.; Carvalho, P.H.D.A.; Rodrigues, M.R.A.; Beira, F.T.A.; Del-Pino, F.A.B. Composition and antiproliferative effect of essential oil of Origanum vulgare against tumor cell lines. J. Med. Food 2014, 17, 1129-1133. [CrossRef]

43. Geran, R.I.; Greenberg, N.H.; Macdonald, M.M.; Schumacher, A.M.; Abbott, B.J. Protocols for screening chemical agents and natural products against animal tumours and other biological systems. Cancer Chemother. Rep. 1972, 3, 59-61.

44. Kaskatepe, B.; Yildiz, S.S.; Kiymaci, M.E.; Yazgan, A.N.; Cesur, S.; Erdem, S.A. Chemical composition and antimicrobial activity of the commercial Origanum onites L. oil against nosocomial carbapenem resistant extended spectrum beta lactamase producer Escherichia coli isolates. Acta Boil. Hung. 2017, 68, 466-476. [CrossRef]

45. Pezzani, R.; Vitalini, S.; Iriti, M. Bioactivities of Origanum vulgare L.: An update. Phytochem. Rev. 2017, 16, 1253-1268. [CrossRef]

46. Moshayedi, S.; Shahraz, F.; Schaffner, D.W.; Khanlarkhani, A.; Shojaee-Aliabadi, S.; Shahnia, M.; Khaksar, R. In Vitro control of Enterococcus faecalis by Zataria multilfolira Boiss, Origanum vulgare L. and Mentha pulegium essential oils. J. Food Saf. 2013, 33, 327-332. [CrossRef]

47. Teixeira, B.; Marques, A.; Ramos, C.; Serrano, C.; Matos, O.; Neng, N.R.; Nogueira, J.M.F.; Saraiva, J.A.; Nunes, M.L. Chemical composition and bioactivity of different oregano (Origanum vulgare) extracts and essential oil. J. Sci. Food. Agric. 2013, 93, 2707-2714. [CrossRef] [PubMed] 
48. Kačániová, M.; Vukovič, N.; Horská, E.; Šalamon, I.; Bobková, A.; Hleba, L.; Mellen, M.; Vatlák, A.; Petrová, J.; Bobko, M. Antibacterial activity against Clostridium genus and antiradical activity of the essential oils from different origin. J. Environ. Sci. Heal. Part B 2014, 49, 505-512. [CrossRef] [PubMed]

49. Jnaid, Y.; Yacoub, R.; Al-Biski, F. Antioxidant and antimicrobial activities of Origanum vulgare essential oil. Int. Food Res. J. 2016, 23, 1706-1710.

50. Adrar, N.; Oukil, N.; Bedjou, F. Antioxidant and antibacterial activities of Thymus numidicus and Salvia officinalis essential oils alone or in combination. Ind. Crop. Prod. 2016, 88, 112-119. [CrossRef]

51. Adams, R.P. Identification of essential oil components by Gas Chromatography/Mass Spectrometry; Allured: Carol Stream, IL, USA, 2007.

52. Hochmuth, D. Mass Spectral Library "Terpenoids and Related Constituents of Essential oils"; Library of MassFinder 3: Hamburg, Germany, 2006.

53. Bhunia, A.; Johnson, M.C.; Ray, B. Purification, characterization and antimicrobial spectrum of a bacteriocin produced by Pediococcus acidilactici. J. Appl. Bacteriol. 1988, 65, 261-268. [CrossRef]

54. King, E.O.; Ward, M.K.; Raney, D.E. Two simple media for the demonstration of pyocyanin and fluorescin. J. Lab. Clin. Med. 1954, 44, 301-307.

55. Soylu, E.M.; Kurt, S.; Soylu, S. In vitro and in vivo antifungal activities of the essential oils of various plants against tomato grey mould disease agent Botrytis cinerea. Int. J. Food Microbiol. 2010, 143, 183-189. [CrossRef]

56. Zygadlo, J.A.; Guzmán, C.A.; Grosso, N.R. Antifungal properties of the leaf oils of Tagetes minuta L. and T. filifolia Lag. J. Essent. Oil Res. 1994, 6, 617-621. [CrossRef]

57. Brand-Williams, W.; Cuvelier, M.; Berset, C. Review: Use of a free radical method to evaluate antioxidant activity. Food Sci. Technol. 1995, 28, 25-30.

58. Lee, S.K.; Zakaria, H.M.; Cheng, H.; Luyengi, L.; Gamez, E.J.; Mehta, R.G.; Kinghorn, A.D.; Pezzuto, J.M. Evaluation of the antioxidant potential of natural products. Comb. Chem. High Throughput Screen. 1998, 1, 35-46. [PubMed]

59. Caputo, L.; Souza, L.F.; Alloisio, S.; Cornara, L.; De Feo, V. Coriandrum sativum and Lavandula angustifolia essential oils: Chemical composition and activity on central nervous system. Int. J. Mol. Sci. 2016, 17, 1999. [CrossRef] [PubMed]

60. Caputo, L.; Nazzaro, F.; Souza, L.F.; Aliberti, L.; De Martino, L.; Fratianni, F.; Coppola, R.; De Feo, V. Laurus nobilis: Composition of essential oil and its biological activities. Molecules 2017, 22, 930. [CrossRef] [PubMed]

61. Van Meerloo, J.; Kaspers, G.J.L.; Cloos, J. Cell sensitivity assays: The MTT assay. Adv. Struct. Saf. Stud. 2011, 731, 237-245.

62. Hammer, O.; Harper, D.A.T.; Ryan, P.D. PAST: Paleontological statistics software package for education and data analysis. Palaeontol. Electron. 2001, 4, 1-9. 